\title{
PERUBAHAN FONOLOGIS DALAM KASUS TA'RIB (ARABISASI) PADA RUBRIK FOTOGRAFI MEDIA AL-JAZEERA
}

\author{
Ilfiana Iffah Jihada \\ ilfianaiffahjihada@gmail.com
}

\begin{abstract}
Abstrak
Bahasa Arab memiliki ciri dan tanda khusus, terutama pada kosakata. Bahasa Arab kaya dengan kosakata, ditambah lagi dengan adanya pemindahan bahasa Asing ke dalam bahasa Arab yang semakin memperkaya kosakata bahasa Arab. Pemindahan kosakata Asing ke dalam bahasa Arab ini disebut dengan Arabisasi (ta 'rib). Pembentukan kata atau istilah dalam ta'ribdapat dilakukan dengan cara menyerap kata asing (yang dimaksud Inggris) ke dalam bahasa Arab. Penyerapan ini mengalami perubahan fonologi sesuai dengan kaidah bahasa Arab. Perubahan fonologi yang terjadi pada penyerapan tersebut adalah asimilasi fonetis dan asimilasi fonemis.asimilasi fonetis terjadi karena perubahannya masih dalam lingkup alofon dari satu fonem, misalnya fonem $/ \mathrm{p} /$ berubah menjadi fonem /b/ atau dalam bahasa Arab (ب) karena fonem /p/ merupakan alofon dari fonem $/ \mathrm{b} /$. Sedangkan asimilasi fonemis terjadi karena perubahannya pada lingkup dua fonem yang berbeda. Misalnya fonem /g/ dalam bahasa Arab berubah menjadi fonem $/ \mathrm{j} /$ atau (ج). Bunyi /g/ merupakan alofon dri fonem /g/ dan fonem /j/ merupakan alofon dari fonem $/ \mathrm{j} /$.
\end{abstract}

Kata Kunci: Arabisasi (ta'rib), Kosakata Asing dan Perubahan Fonologis.

\section{Pendahuluan}

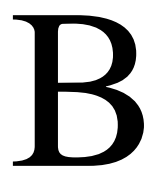

ahasa adalah sistem lambang bunyi yang arbitrer, digunakan untuk saling bertukar pikiran dan perasaan antar anggota kelompok masyarakat bahasa. ${ }^{1}$ Bahasa merupakan kumpulan simbol yang digunakan sebagai alat untuk menyampaikan pemikiran maupun perasaan kepada mitra bicara. Ia menjadi produk budaya dan peradaban yang selalu berkembang seiring dengan kemajuan zaman, terlebih lagi pada masa modern saat ini dengan perkembangan ilmu dan teknologi yang melesat maju, tentunya bahasa pun ikut mendapatkan dampaknya tidak terkecuali dengan bahasa Arab yang menjadi bahasa utama di sebagian besar negara Timur Tengah. Bahasa Arab adalah salah satu bahasa Semit, yang termasuk dalam rumpun bahasa Semit dan berkerabat dengan bahasa Ibrani dan bahasa-bahasa Neo-Arami. Bahasa Arab memiliki lebih

${ }^{1}$ Barokatussolihah, Belajar Bahasa Arab dengan Bernyanyi (Yogyakarta: Safiria Insania Press, Cet. 1, 2013), 2. 
banyak penutur dari pada bahasa-bahasa lainnya dalam rumpun bahasa semit. ${ }^{2}$ Bahasa Arab memiliki ciri atau tanda-tanda yang khusus, misalnya pada aspek kosakata. Ciri khas yang dimiliki bahasa Arab adalah pola pembentukan kata yang sangat fleksibel, baik melalui derivasi maupun dengan cara infleksi. Dengan melalui dua cara pembentukan kata ini, bahasa Arab menjadi sangat kaya dengan kosakata. ${ }^{3}$ Ketika bahasa bertemu dengan fenomena modernitas baik dari sisi ilmu, teknologi, dan budaya, ia akan mulai bertemu dengan istilah-istilah baru. Di sinilah terjadi kontak bahasa sebagai pengaruh bahasa yag satu kepada bahasa yang lain. Bahasa Arab banyak dipengaruhi oleh bahasa-bahasa lain sesuai dengan perkembangan ilmu pengetahuan dan teknologi di Barat. Hal ini menjadi penyebab adanya bentuk penyerapan kosakata Arab dari bahasa asing, sehingga memperkaya kosakata bahasa Arab. Salah satu contohnya bisa kita jumpai dalam media online Al-Jazeera.

Al-Jazeera merupakan satu-satunya stasiun tv yang independen secara politik di Timur Tengah. Al-Jazeera juga mengoperasikan situs web berbahasa Arab dan inggris. ${ }^{4}$ Dalam tulisan ini kosakata bahasa Arab yang diserap dari bahasa Asing dapat diambil dari rubrik الوسائط bagian photographic di Aljazeera.net edisi 1 februari sampai dengan 10 Maret 2017. Al Jazeera.net sebagai media internasional berperan penting sebagai jembatan informasi bagi masyarakatnya untuk mengetahui perkembangan masa kini baik perihal dalam dan luar negeri. Photografi pada media online al-Jazeera yang akan diteliti oleh penulis merupakan sebuah media dengan berbagai gagasan, cerita, dan peristiwa, tidak hanya berupa gambar tetapi juga dengan tulisan yang berupa kata maupun kalimat. Photografi pada media online al-Jazeera tersebut memiliki banyak katakata asing baru yang diarabkan atau biasa disebut arabisasi. Kosakata pada photografi tersebut terbatas pada nama-nama diri, yaitu nama benda, nama tempat, nama tim sepak bola, nama penyakit, dan nama orang.

Kosakata asing yang diarabisasikan dapat mengalami perubahan pengucapan dan penulisan pada beberapa kosa kata asing atau munculnya istilah baru. Hal ini tentunya memunculkan kesulitaan tersendiri bagi penutur bahasa Arab dari bangsa Arab itu sendiri, ataupun bangsa di luar Arab. Fenomena perkembangan bahasa ini terjadi secara alami dan akan terus berkembang selama manusia masih saling berinteraksi antara satu dengan yang lainnya, baik dengan kesadarannya dalam berbahasa ataupun sebaliknya, karena di dalam soal pungutan bahasa Asing itu sendiri, dapat berlaku segera atau dapat pula memakan waktu

${ }^{2}$ Toni Pransiska, Pendidikan Bahasa Arab di Indonesia: Historisitas danRealitas (Yogyakarta: Ombak, 2015), 49.

${ }^{3}$ Ibid., 65.

${ }^{4}$ https://id.m.wikipedia.org/wiki/Al_Jazeera, jumat 31 maret 2017, 18.55. 
yang lama. ${ }^{5}$ Bahasa Arab dengan bahasa asing yang diserap memiliki perbedaan, seperti dalam hal bunyi, baik itu bunyi vokal maupun bunyi konsonan. Di samping itu, ada perbedaan dalammakhraj, sistem aksara, ejaan, alphabet, jenis dan jumlah huruf dalam tulisan. Hal ini tentunya menarik penulis untuk mengamati dan menelaah lebih lanjut mengenai penyerapan kata dalam photografi yang digunakan oleh media online Al Jazeera.

Dalam tulisan ini peneliti berupaya untuk memfokuskan kajian arabisasi pada kata atau istilah dari bahasa asing ke dalam bahasa Arab dengan menggunakan analisis fonologi. Adapun teori fonologi bertugas mempelajari fungsi bunyi untuk membedakan atau mengidentifikasi kata-kata tertentu.Teori ini dapat membantu penulis dalam menganalisa dan mengkaji tulisan dari hasil adaptasi fonologis dalam penyerapan kosakata-kosakata Asing pada photografi yang terjadi di media online al-Jazeera.

\section{Kontak Bahasa}

Kontak bahasa merupakan peristiwa penggunaan lebih dari satu bahasa dalam tempat dan waktu yang sama. Kontak bahasa terjadi dalam masyarakat pemakai bahasa atau terjadi dalam situasi kemasyarakatan tempat seseorang mempelajari unsur-unsur sistem bahasa yang bukan bahasanya sendiri. Kontak bahasa meliputi segala peristiwa persentuhan antara dua bahasa atau lebih yang berakibat adanya perubahan unsur bahasa oleh penutur dalam konteks sosialnya. Ciri yang menonjol dari persentuhan bahasa adalah terdapatnya kedwibahasaan atau bilingualisme. ${ }^{6}$ Bilingualisme adalah penggunaan dua bahasa oleh seorang penutur dalam pergaulannya dengan orang lain secara bergantian. ${ }^{7}$ Bilingualisme timbul akibat adanya kontak bahasa. Kontak bahasa terjadi apabila dua bahasa atau lebih dipakai secara bergantian, sehingga mangakibatkan terjadinya pemindahan unsur dari bahasa satu ke bahasa yang lain.

Pada masa Jahiliyyah, orang-orang Arab mengadakan kontak dengan orang-orang Persia, Romawi dan bangsa-bangsa lain yang berdekatan dengan Arab. Secara tidak langsung bahasa Arab pun bersentuhan dengan bahasa yang digunakan oleh orang Persia maupun Romawi. Dan pengaruh dari persentuhan itu adalah adanya penggantian antar bahasa dan pengambilan atau adopsi bahasa lain. Bahasa Arab mengambil kata bahasa lain yang berdekatan dengannya, yang biasa disebut dengan al-kalimat al-muarrabah (kata-kata yang diarabkan), sedangkan proses pengambilannya disebut dengan ta'rib (arabisasi). Seiring dengan

${ }^{5}$ Halim Barakat, Dunia Arab:Masyarakat, Budaya, dan Negara (Bandung: Penerbit Nusa Media, 2012), 64.

6 Aslinda, Leni Syafyahya, Pengantar Sosiolinguistik, (Bandung: Refika Aditama, cet. 1, 2007), 25.

${ }^{7}$ Abdul Chaer, Leoni Agustina, Sosiolinguistik: Perkenalan Awal, (Jakarta: Rineka Cipta, 2014), 84 . 
perkembangan zaman, bangsa Arab mengadakan kontak dengan bangsa lain di dunia, termasuk Barat. Perkembangan ilmu pengetahuan, teknologi, dan informasi di Barat telah mempengaruhi perkembangan bahasa Arab. Sehingga bahasa Arab harus menyesuaikan diri dengan bahasa yang dibawa oleh Barat dengan cara memunculkan istilah-istilah baru, bahasa Arab harus melakukan penerjemahan, dan bahasa Arab juga bisa melakukan penyerapan kata baru dari bahasa asing dengan menyesuaikannya dengan kaidah-kaidah bahasa Arab. Maka lahirlah istilah ta'rib (arabisasi).

\section{Ta'rib (Arabisasi)}

Ta'rib atau arabisasi merupakan bahasan mengenai kata serapan dan dianggap sebagai perkembangan makna dalam bahasa Arab. Kata-kata yang terarabisasi atau kata-kata asing yang diarabkan sudah dipergunakan dalam priode pra-Islam, khususnya peminjaman dari bahasa Aramik, Persia, dan Ibrani. Dalam al-Quran sendiri, ada beberapa istilah yang asal-usulnya dapat dirunut dari bahasa lain. ${ }^{8}$ Proses arabisasi dalam bahasa Arab terhadap penyerapan bahasa asing terdapat empat macam, yaitu: ad-Dakhil, Taulid, at-Ta'rib, dan Tarjamah. ${ }^{9}$ Adapun dalam tulisan ini yang akan menjadi fokus penulis dalam fenomena arabisasi itu sendiri adalah hanya dalam lingkup at-Ta'rib.

At-Ta'rib muncul sebagai akibat dari masuknya bahasa asing pada bahasa Arab yang mengalami perubahan pada sebagian bentuknya. Sebelum istilahta'rib ini muncul, terdapat istilah al-muwallad yang muncul sebagai akibat ketidaktahuan orang-orang Arab akan istilah-istilah baru yang dipergunakan. Namun dalam perjalanannya istilah al-muwallad ini tidak dikenal sehingga muncul istilah ta'rib. Secara etimologi ta'rib berasal dari bahasa Arab dan merupakan bentuk masdar dari kata kerja عرّب, memiliki makna penerjemahan dalam bahasa Arab, atau memindahkan bahasa asing ke dalam bahasa Arab. Adapun secara terminologi ta'rib adalah penyerapan unsur-unsur asing baik berupa kata maupun istilah. Ta'rib adalah kata serapan yang sudah dibentuk dan diubah sesuai dengan kaidah bahasa Arab. ${ }^{10}$ at-Ta'rib adalah mengambil atau meminjam atau menerjemahkan istilah bahasa asing ke dalam bahasa Arab berdasarkan kaidah-kaidah yang telah diterapkan oleh orang Arab dalam arabisasi (bisa dengan memanfaatkan wazan atau derivasinya). ${ }^{11}$

${ }^{8}$ Sayyed Hossein Nasr, Oliver Leaman, Ensiklopedi Tematis Filsafat Islam, (Yogyakarta: Mizan), 1220.

${ }^{9}$ Mukaram, Abdul 'Ali Salim,at-Ta'rib fi at-Taratsi al-Lugawiy Muqayisihi wa 'Alamatihi, (Kairo: Maktabah 'Ilmi al-Kitab, 2001), hlm. 41

${ }^{10}$ Abdul Malik, Arabisasi dalam Bahasa Arab: Tinjauan Deskriptif-Historis, Adabiyat, Vol. 8, No. 2 (Yogyakarta: Pascasarjana UIN Sunan Kalijaga, 2009), 265.

${ }^{11}$ Nurul Azmi, Dakhil dan Mu'arrab, (Yogyakarta: Makalah Kelas, Pasca Sarjana UIN Sunan Kalijaga, 2015), 3. 
Sebagian ahli bahasa Arab tidak mudah menerima ta'rib, karena mereka beranggapan bahwa ta'rib atau arabisasi dapat menyebabkan masuknya kata-kata asing yang pada akhirmya akan merusak bahasa, menghilangakan identitas, karakteristik, dan sifat asli bahasa Arab. Namun sebagian ahli bahasa Arab mendukung adanya ta'rib karena kata-kata yang diarabkan mengikuti kaidahkaidah yang sesuai dengan kondisi bahasa Arab, sehingga tidak akan menghilangkan ciri-ciri kearabannya. Pembentukan kata atau istilah dalam ta'rib dapat dilakukan dengan cara penyerapan, penerjemahan, dan pembentukan istilah baru (isytiqaq dengan membentuk wazan).Proses pembentukan kata dengan penerjemahan dari bahasa Asing merupakan dampak dari perkembangan ilmu pengetahuan modern, misalnya pada kata ilmu (logy) diterjemahkan dengan lujiya, seperti phonology (فونولوجيا).

Sedangkan untuk membentuk istilah baru dalam melakukan arabisasi dari bahasa asing digunakan isytiqaq atau wazanyang ada dalam bahasa Arab. Dalam tulisan ini, pembentukan kata dalam ta'rib dilakukan dengan cara penyerapan. Penyerapan kata maupun istilah asing dalam bahasa Arab mengalami perubahan fonologis sesuai dengan ketentuan dalam bahasa Arab. Kasus fonologis menjadi kasus yang umum dalam tataran linguistik, karena kasus ini merupakan tahapan awal setelah kata-kata asing diserap oleh bahasa Arab yang sesuai dengan kaidahkaidah bahasa Arab. Kasus fonologis ini melihat adanya perubahan fonem pada kata asing yang diarabkan sesuai dengan kaidah bahasa Arab.

\section{Bentuk Perubahan Fonologis pada Kosakata Asing dalam Bahasa Arab}

Pembentukan kata atau istilah baru dalam ta'rib dapat dilakukan dengan penyerapan. Penyerapan kata maupun istilah asing dalam bahasa Arab dapat mengalami perubahan fonologis. Apabila perubahan itu tidak sampai mengubah identitas fonem, maka bunyi-bunyi tersebut masih merupakan alofon atau varian bunyi dari bunyi yang sama (perubahan fonetis). Tetapi, apabila perubahan bunyi itu sudah sampai mengubah identitas fonem, maka bunyi-bunyi tersebut merupakan alofon dari fonem yang berbeda (perubahan fonemis). ${ }^{12}$

Perubahan fonologi yang terjadi pada kata-kata yang diserap dari bahasa Inggris disesuaikan dengan pelafalan yang biasa atau lazim dalam bahasa Arab.

a. Ada perubahan suara yang terwujud dalam perubahan huruf dalam kata yang diserap, biasa disebut asimilasi fonetis. Adanya perubahan fonem $/ \mathrm{p} / \mathrm{menjadi}$ fonem /b/ atau (ب), seperti pada kata Liverpool (ليفربول), Paris Saint Germain (باريس سان جيرمان), Potassium (البوناسيم), dan Protestantism (لبرون), (برونتانتية).

\footnotetext{
${ }^{12}$ Masnur Muslich, Fonologi Bahasa Indonesia: Tinjauan Deskriptif Sistem Bunyi Bahasa Indonesia (jakarta: Bumi Aksara, 2014), 118.
} 
Perubahan fonem /p/ menjadi fonem /b/ pada kata-kata yang telah disebutkan di atas tergolong asimilasi fonetis karena perubahannya masih dalam lingkup alofon dari satu fonem, yaitu fonem $/ \mathrm{b} /$.

b. Ada perubahan yang terjadi pada fonem tertentu menjadi fonem tertentu yang lain, biasa disebut asimilasi fonemis.

1) Fonem /c/ dan /ch/ (dengan variasi bacaannya) berubah menjadi fonem /s dan sy/ atau (ش- سرشلونة), seperti pada kata Barcelona (برش), Manchester United (نشانشستر يونايتد), Chelsea (نشلسي), Facebook (فيسبونة), dan Ac Milan

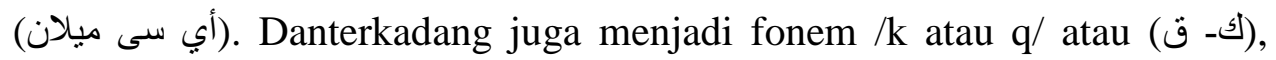
seperti pada kata Electronic (إلكتروني), Catholic (الكاثوليكية), Symantec (سيمانتاك), danCholesterol (الكولسترول). Di samping itu terjadi perubahan fonem /ch/ menjadi /kh/, seperti pada kataBayern Munchen (بايرن ميونيخ).

2) Fonem /v/ berubah menjadi fonem /f/ atau (ف), seperti pada kata Juventus (يوفنتوس) danVirus (فيروس).

3) Fonem /ph/ berubah menjadi fonem /f/ atau (ف), seperti pada kata Telegraph (التلغر اف) dan Demographic (ديمغر اف).

4) Fonem /s/ berubah menjadi /sh/ atau (ص),seperti pada kata Sodium (الصوديوم).Dan terkadang juga fonem /s/ bisa berubah menjadi fonem /z/ atau (j), seperti pada kata gas (غاز) dan transistor (التزانزستور)).

5) Fonem /g/ berubah menjadi /j/ atau (ج), seperti pada kata oksigen (الأكسجين), nigeria (نيجيريا).

c. Perubahan fonem dari [c/ch] ke [s/sy/k] merupakan lingkup dua fonem yang berbeda karena bunyi [c/ch] merupakan alofon dari dari fonem [c], bunyi [s/sy] merupakan alofon dari bunyi [s], dan bunyi [k] merupakan alofon dari bunyi [k]. Begitu juga dengan perubahan fonem dari [v] ke [f] dan perubahan fonem dari [ph] ke [f] yang merupakan dua fonem yang berbeda. Di samping itu, ada juga perubahan fonem dari $[\mathrm{s}] \mathrm{ke}[\mathrm{z}]$ dan dari [s] ke [sh] yang juga merupakan dua fonem yang berbeda.

d. Dalam bahasa Arab, vokal a, i, dan u sebenarnya tidak mempunyai lambang bunyi dalam bentuk huruf. Akan tetapi a, i, dan u hanya merupakan tanda kasus (harakat). ${ }^{13}$ Menurut Ibnu Jinni sebagaimana dikutip oleh Ibrahim Anis dan dikutip pula oleh Ahmad Sayuti Anshari Nasution mengatakan bahwa harakat adalah sebagaian dari huruf mad atau huruf lain. Huruf mad ada tiga yaitu alif, waw, dan ya maka harakat juga ada tiga yaitu fathah, dhammah, dan

${ }^{13}$ Erwina Burhanuddin, Abdul Gaffar Ruskhan, R.B. Chrismanto, Penelitian Kosakata Bahasa Arab dalam Bahasa Indonesia (Jakarta: Departemen Pendidikan dan Kebudayaan, 1993), 6. 
kasrah. Fathah sebagian dari alif, dhammah sebagian dari waw, dan kasrah sebagian dari $y a .^{14}$

Penyerapan kata atau istilah asing dalam bahasa Arab diperlukan penyesuaian lafaldengan cara menambahkan vokal panjang /âa/, /1̄/, dan /u/.

$$
\begin{aligned}
& \text { Misalnya: } \quad \text { Real Madrid } \longrightarrow \text { reāl madrīd (بإل مدربد). } \\
& \text { Arsenal } \longrightarrow \text { arsenāl (أرسنال). } \\
& \text { Radio } \longrightarrow \text { rādio (راديو). } \\
& \text { Trilliun } \longrightarrow \text { trilliūn (ترليون). }
\end{aligned}
$$

Di samping itu, terdapat perubahan vokal /o/ menjadi /u/, seperti pada kata Million menjadivهرمون(murmūn), Kilo byte menjadiskiilū bāit). Ada juga perubahan vokal /e/ menjadi /i/, seperti pada kata Internet menjadiإنترنت(intirnit) Meter menjadi(mitr), Arsenal menjadiأرسنال(arsināl). Dalam sebuah koskata yang diarabisasikan dari bahasa asing tidak hanya terjadi perubahan satu fonem pada kosakata tersebut, tetapi bisa terjadi perubahan beberapa fonem pada satu kosakata yang diarabisasikan. Di sini

\begin{tabular}{|c|c|c|c|}
\hline $\begin{array}{c}\text { Kata atau Istilah } \\
\text { dalam Fotographic } \\
\text { Aljazeera.net }\end{array}$ & Perubahanya & $\begin{array}{c}\text { Fonem yang } \\
\text { Berubah }\end{array}$ & \begin{tabular}{|c|} 
Asal Kata atau \\
Istilah dalam Bahasa \\
Latin atau \\
Inggrisnya \\
\end{tabular} \\
\hline بنغلاديش & Iy & $\mathrm{E}$ & Bangladesh \\
\hline ليبيا & $\overline{\mathrm{A}}$ & A & Libia \\
\hline فيسبوك & $\overline{\mathrm{U}}$ & $\mathrm{O}$ & Facebook \\
\hline مارك زكربيرغ & $\tilde{a}, \mathrm{k}, \hat{\mathrm{y}}$ & $\mathrm{a}, \mathrm{ck}, \mathrm{e}$ & Mark Zuckerberg \\
\hline هرمونات & û, nãt & $\mathrm{o}, \mathrm{n}$ & \begin{tabular}{|l|} 
Hormon \\
\end{tabular} \\
\hline كولسترول & $\mathrm{k}, \hat{\mathrm{u}}$, & $\mathrm{ch}, \mathrm{o}$ & Cholesterol \\
\hline بوتاسيوم & bû, s, yû, & $\mathrm{p}, \mathrm{o}, \mathrm{ss}, \mathrm{iu}$ & Potassium \\
\hline الصوديوم & $\mathrm{sh}, \mathrm{u}$ & $\mathrm{s}, \mathrm{o}$ & Sodium \\
\hline دونالا نرمب & $\overline{\mathrm{u}},-, \mathrm{b}$ & $o, u, p$ & Donald Trump \\
\hline الأونروا & $\overline{\mathrm{u}}, \overline{\mathrm{a}}$ & $\mathrm{u}, \mathrm{a}$ & Unrwa \\
\hline ديمغر افي & iy, $f$, & $\mathrm{e}, \mathrm{ph}$ & Demographic \\
\hline سان برناردينو & $\tilde{\mathrm{a}}, \overline{\mathrm{u}}$ & $\mathrm{a}, \mathrm{o}$ & San Bernardino \\
\hline باكستان & $\mathrm{b}, \tilde{a}$ & $\mathrm{p}, \mathrm{a}$ & Pakistan \\
\hline
\end{tabular}
penulis lebih merincikan perubahan-perubahan tersebut pada tabel berikut ini dengan menunjukkan kata dan istilah serapan sekaligus menunjukkan perubahanperubahan fonologisnya.

${ }^{14}$ Ahmad Sayuti Anshari Nasution, Bunyi bahasa: Ilm Al-Ashwat Al-Arabiyyah (Jakarta: Amzah, 2009), 88. 


\begin{tabular}{|c|c|c|c|}
\hline $\begin{array}{c}\text { Kata atau Istilah } \\
\text { dalam Fotographic } \\
\text { Aljazeera.net }\end{array}$ & Perubahanya & $\begin{array}{c}\text { Fonem yang } \\
\text { Berubah }\end{array}$ & $\begin{array}{c}\text { Asal Kata atau } \\
\text { Istilah dalam Bahasa } \\
\text { Latin atau } \\
\text { Inggrisnya }\end{array}$ \\
\hline نيو جيرسى & Yũ & Ew & New Jersey \\
\hline نيويورك & Yũ & Ew & New York \\
\hline الأكسجين & $\cdot, \mathrm{j}, \mathrm{i}$ & $\mathrm{o}, \mathrm{g}, \mathrm{e}$ & Oksigen \\
\hline فلايت & Lãyt & Light & Flight \\
\hline الفيتو & $\mathrm{i}, \mathrm{u}$ & $\mathrm{e}, \mathrm{o}$ & Veto \\
\hline نيجيريا & $\mathrm{J}, \mathrm{i}$ & $\mathrm{g}, \mathrm{e}$ & Nigeria \\
\hline 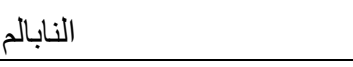 & $\mathrm{B}$ & $\mathrm{P}$ & Napalm \\
\hline غاز & $\mathrm{Z}$ & $S$ & Gas \\
\hline فى إكس & $\mathrm{f}, \mathrm{iks}$ & $\mathrm{v}, \mathrm{x}$ & VX \\
\hline أنزيم & ‘ & $\mathrm{e}$ & Enzyme \\
\hline ريبال مدريد & $\mathrm{e}, \overline{1}$ & $\mathrm{e}, \mathrm{i}$ & Real madrid \\
\hline بايرن ميونيخ & $\bar{a}, \mathrm{i}, \mathrm{yu}$, nikh & $\mathrm{a}, \mathrm{e}, \mathrm{u}, \mathrm{chen}$ & Bayern munchen \\
\hline يوفنتوس & $\mathrm{y}, \mathrm{f}, \mathrm{i}, \overline{\mathrm{u}}$ & $j, v, e, u$ & Juventus \\
\hline ليفربول & $\overline{1}, \mathrm{f}, \mathrm{i}, \mathrm{b}, \overline{\mathrm{u}}$ & $i, v, e, p$, oo & Liverpool \\
\hline باريس سان جيرمان & $\mathrm{b}, \overline{\mathrm{a}}, \mathrm{n}, \mathrm{j}, \mathrm{i}$ & $\mathrm{p}, \mathrm{ai}, \mathrm{nt}, \mathrm{g}, \mathrm{e}$ & Paris Saint Germain \\
\hline
\end{tabular}

\section{Penutup}

Ta'rib (Arabisasi) dalam bahasa Arab dapat dikatakan sebagai kata serapan, di mana kata-kata yang diserap tersebut telah mengalami perubahan dari segi fonologis sesuai dengan kaidah bahasa Arab. Beberapa kosakata yang sudah dijalaskan di atas dapat kita simpulkan bahwa sebuah kata asing yang diarabisasikan mengalami asimilasi fonetis dan asimilasi fonemis. Asimilasi fonetis terjadi karena perubahan fonem pada kata tersebut masih dalam lingkup alofon dari satu fonem, seperti pada kata Liverpool (للفربول). Ada perubahan fonem /p/ menjadi /b/ atau (ب). Perubahan tersebuttergolong asimilasi fonetis karena perubahannya masih dalam lingkup alofon dari satu fonem, yaitu fonem /b/. Sedangkan asimilasi fenemis terjadi karena perubahan fonem pada kata tersebut merupakan alofon dari fonem yang berbeda, seperti pada kata facebook (فيسبوك). Ada perubahan fonem /c/ menjadi /s/ atau (w). Perubahan tersebut merupakan lingkup dua fonem yang berbeda sehingga disebut asimilasi fonemis. Selain itu, ada beberapa perubahan fonem vokal dengan merubah fonem vokal /e/ dan /o/ dalam kosakata asing menjadi fonem vokal /i/ dan /u/ ketika diarabkan. Di samping itu, kosakata asing yang diarabkan mengalami menambahan vokal panjang $/ \overline{\mathrm{a}} /, \mathbf{1} /$, dan $/ \overline{\mathrm{u}} /$ sesuai dengan kaidah bahasa Arab. 


\section{Daftar Pustaka}

Anshari Nasution, Ahmad Sayuti, Bunyi bahasa: Ilm Al-Ashwat Al-Arabiyyah, Jakarta: Amzah, 2009.

Aslinda, Leni Syafyahya, Pengantar Sosiolinguistik, Bandung: Refika Aditama, 2007.

Azmi, Nurul, Dakhil dan Mu'arrab, Yogyakarta: Makalah Kelas, Pasca Sarjana UIN Sunan Kalijaga, 2015.

Barokatussolihah, Belajar Bahasa Arab dengan Bernyanyi, Yogyakarta: Safiria Insania Press, Cet. 1, 2013.

Barakat, Halim,Dunia Arab:Masyarakat, Budaya, dan Negara,Bandung: Penerbit Nusa Media, 2012.

Chaer Abdul, Agustina Leonie, Sosiolinguistik: Perkenalan Awal, Jakarta: Rineka Cipta, 2014.

Erwina Burhanuddin, Abdul Gaffar Ruskhan, R.B. Chrismanto, Penelitian Kosakata Bahasa Arab dalam Bahasa Indonesia,Jakarta: Departemen Pendidikan dan Kebudayaan, 1993.

Malik, Abdul, Arabisasi dalam Bahasa Arab: Tinjauan Deskriptif-Historis, Adabiyat, Vol. 8, No. 2, Yogyakarta: Pascasarjana UIN Sunan Kalijaga, 2009.

Mukaram, Abdul 'Ali Salim, at-Ta'rib fi at-Taratsi al-Lugawiy Muqayisihi wa 'Alamatihi, Kairo: Maktabah 'Ilmi al-Kitab, 2001.

Muslich, Masnur,Fonologi Bahasa Indonesia: Tinjauan Deskriptif Sistem Bunyi Bahasa Indonesia,jakarta: Bumi Aksara, 2014.

Pransiska, Toni,Pendidikan Bahasa Arab di Indonesia: Historisitas danRealitas, Yogyakarta: Ombak, 2015.

https://id.m.wikipedia.org/wiki/Al_Jazeera, jumat 31 maret 2017, 18.55 